\title{
Organization of oral health actions in primary care from the perspective of dental managers and dentists: process of work, planning and social control
}

\author{
Organização de ações de saúde bucal na atenção básica a partir da perspectiva de gestores em saúde bucal e \\ cirurgiões dentistas: processo de trabalho, planejamento e controle social
}

Sílvia Helena Campos ANDRAUS ${ }^{1}$
Raquel Conceição FERREIRA ${ }^{2}$
João Henrique Lara do AMARAL ${ }^{2}$
Marcos Azeredo Furquim WERNECK²

ABSTRACT

Objective

The aim of this study was to evaluate both the managers' and dental surgeons' perception about the organization of oral health actions in primary care, regarding the work process, planning and social control, in a health micro region.

\section{Methods}

Qualitative study case with the performance of interviews with oral health managers and focal group with dental surgeons. The content analysis proposed by Bardin was used.

\section{Results}

The management of the planning and work process is characterized by isolated actions, low institutional support and verticalized authoritarian processes. In the scope of primary care, there is no integrality nor intersectoriality. The managers and dental surgeons have little access to the fundamental indicators and parameters to the initial diagnosis of the planning.

\section{Conclusion}

The National Program of Improvement to the Access and Quality in Primary Care allowed a possible breakthrough in the current model, with the implementation of new ways of work organization and production, record information, planning and action implementation. There is hardly any social control.

Indexing terms: Community participation. Health planning. Health services management. Integrality in health. Oral health. Work.

\section{RESUMO}

\section{Objetivo}

Avaliar a percepção de gestores e cirurgiões dentistas acerca das principais dificuldades de organização das ações de Saúde Bucal na atenção básica, na microrregião de Ituiutaba (MG), referentes ao processo de trabalho, integralidade, gestão, planejamento e controle social.

\section{Métodos}

Estudo de caso de natureza qualitativa, com realização de entrevistas com os gestores de saúde bucal de cada município e Grupo Focal com cirurgiões dentistas. Análise dos resultados realizada com o emprego do método de análise de conteúdo proposta por Bardin.

\section{Resultados}

A gestão do planejamento e do processo de trabalho dos serviços de Saúde Bucal caracteriza-se por ações isoladas, baixo apoio institucional e processos autoritários verticalizados. No âmbito da atenção básica, não há integralidade e intersetorialidade. Os gestores e os cirurgiões dentistas têm pouco acesso aos indicadores e parâmetros que são fundamentais aos diagnósticos iniciais do planejamento. Ainda predomina o modelo de atenção baseado na demanda espontânea.

\section{Conclusão}

O Programa Nacional de Melhoria do Acesso e da Qualidade na Atenção Básica significou o momento de maior possibilidade de superação do atual modelo, com a instauração de novas formas de organizar o trabalho, de produzir, registrar informações, de planejar e implantar as ações. O controle social praticamente inexiste.

Termos de indexação: Participação comunitária. Planejamento em saúde. Administração de serviços de saúde. Integralidade em saúde. Saúde bucal. Trabalho.

\section{INTRODUCTION}

In Brazil, the last five decades of the twentieth century, have brought the development of oral health services marked by a scientist model focused both on the disease as well as the clinical and preventive, care of primary school students, besides emergencies and pregnant women ${ }^{1}$ favoring the exclusion of a large part

\footnotetext{
${ }^{1}$ Universidade Federal de Minas Gerais, Faculdade de Odontologia, Programa de Pós-graduação em Odontologia. Av. Antônio Carlos, 6627, Campus Pampulha, 31270-901, Belo Horizonte, MG, Brasil. Correspondência para / Correspondence to: SHC ANDRAUS. E-mail: <silviaandraus@gmail.com>

${ }^{2}$ Universidade Federal de Minas Gerais, Faculdade de Odontologia. Belo Horizonte, MG, Brasil.
} 
of the population from oral health care, in addition to social inequalities.In 2004, the launching of the guidelines of the National Oral Health Policy (NOHP), known as the "Smiling Brazil", inserted oral health into the public policy agenda ${ }^{2}$. The NOHP is the Unified Health System policy directed to the population's oral health. Based on the paradigm of Health Promotion, it starts from an expanded conception which entitles people's health and presents, as essential foundations for the achievement of this right. It sees integrality as a combination of integral and intersectoral actions of prevention, promotion, treatment and recovery of health, and access as the production of a set of services regarding care and attention to people's oral health. It also reaffirms the importance of citizens' democratic participation, individual and collective, and seeks to respond to the population's health needs ${ }^{3}$. NOHP implantation has accelerated the process of insertion of Oral Health into the Family Health Strategy (FHS), generated a spontaneous increase of oral health teams, expanding the coverage of oral health services in Primary Care (PC) and created The Centers of Dental Specialty $(C D S)^{3}$. Despite the unquestionable progress made with the NOHP, its implementation process has presented weakness in the following features: management, changes in the work process, effectiveness of oral health promotion strategies and permanent education, consolidation of secondary care and population participation ${ }^{4}$. Mainly the work process, planning and social control need to be better understood, in this scenario ${ }^{5}$.

At the Health microregion of the city of Ituiutaba, State of Minas Gerais (MG), located in the Northern Health Region, the organization of the Oral Health services in the PC has been characterized by a recent insertion in the FHS and there have been no official records on management and planning procedures, nor on the organization of the work process and social control.

This study evaluated the perception of dental managers and dentists about the organization of Primary Care Oral Health actions, considering the guidelines of the $\mathrm{NOHP}$, in the micro region of Ituiutaba (MG), regarding the work process, planning and social control.

\section{METHODS}

The study consists of a qualitative exploratory and explanatory case study aiming to understanding either phenomena or organizational and political processes. They are exploratory studies once they search for information about a particular issue that one wishes to study and explanatory since it looks for several arguments from different sources with the aim of enhancing the discussion and propositions regarding the object ${ }^{6-7}$. This is a useful method when the study object is wide and complex and in situations where the best strategy is to get to know it in the context itself, where it occurs. This study was carried out in the institutional area of the Health Microregion of the city of Ituiutaba, State of Minas Gerais (MG), and comprises nine municipalities: Cachoeira Dourada, Campina Verde, Canápolis, Capinópolis, Centralina, Gurinhatã, Ipiaçu, Ituiutaba, km²Santa Vitória, Campina Verde, Canápolis and Centralina ${ }^{8}$. This micro-region has a territorial extension of $13,558.7 \mathrm{~km}^{2}$ and an estimated population of 193,506 inhabitants $^{9}$. The health services were organized in a consortium in order to rationalize the equipment use, human resources and hospital facilities ${ }^{10}$. Regarding oral health, the municipalities of the microregion had, by 2015, 60 dentists attending the Unified Health System (UHS) with a population coverage of $54.7 \%^{11}$. Fifteen professionals participated in the study: technical reference in oral health of the Regional Health Management (RHM), representative of the State Health Department of Minas Gerais (SHD-MG), eight managers in charge of the oral health sector of the municipalities and six dentists belonging to Primary Care area.Semi-structured individual interviews were conducted with the managers and a focus group with dentists. The guidelines for the interviews and focus group was unique and adapted from the Program for Improving Access and Quality of Primary Care (PIAQ- PC). The guidelines included the transversal dimension to the object of the study (NOHP, integrality of attention, management and evaluation) and others directly related to the object (planning, work process and social control). The guidelines were previously tested and there was no need to change. The interviews with the managers were carried out in places and dates previously defined with each interviewee. The focus group with dentists was held in the city of Ituiutaba. Participants were nominated by their coordinators and should have been at least one year working in the Oral Health Team (OHT) and the same script of the interviews was used. Data collection was performed between August and September, 2016. The interviews were carried out by the main researcher and the focus group by the research team. At the beginning of each interview period, a Free and Informed Consent Term (FICT) was read and signed by the participants. The interviews and the focus group were recorded and 
transcribed. The material obtained will be secretly stored for five years and then it will be destroyed. The material analysis was performed in three stages. In the first one, a pre-analysis was carried out and it consisted of free reading, with the purpose of knowledge and orientation of the analysis, definition of its key words and categories. On the second phase the material was explored through exhaustive reading and categorization of the responses. In the third phase, the results were guided according to inference and interpretation, relating the data obtained in the interview to the theoretical framework used ${ }^{12-13}$. The method of content analysis proposed by Bardin was used. To ensure confidentiality, the interviews were identified by two letters, the first "I" (interview) and the second, in alphabetical order, according to their accomplishment order, and for the participants in the focus group the initial FG followed by the sequence number in which that appears in the recording. The Theoretical - Logical framework considered as transversal themes to the NOHP: the National Primary Care Policy (NPCP), the National Health Promotion Policy (NHPP), integrality, management and evaluation in oral health.

Public Policies: By joining the National Primary Care Policy (NPCP), and), the National Health Promotion Policy (NHPP) proposals, the National Oral Health Policy (NOHP) introduced new actions which created the need for changes in the work process of the health unit teams, in a multi- and / or interprofessional way ${ }^{14}$.

The National Oral Health Policy (NOHP) care model proposes that during the implementation of oral health actions and services, the social health determinants be considered along with the best possible response to individual and collective problems and demands, through available resources, in each place ${ }^{15}$. The National Oral Health Policy adopted the Family Strategy Team(FST) as a possible source of actions and services reorientation at the municipal and regional levels. It is of crucial importance that a relationship be established with the social movements and social control in and intersectoral actions, as well as ${ }^{14}$.

Integrality: In this study, the integrality of care encompasses how service organization is carried out, the work process and the oral health service relationship with the health system and society ${ }^{14}$.

Integrality linked to intersectoriality along with the territorial approach enlarges the OHT field of work, enabling the knowledge about factors which endanger people's life and health (environment, society organization, ways of living and relate). Different values, beliefs, and behavior, as well as the identification of the different equipment and social movements with which to work together can also be accomplished.

Management: Management and administration, a process of a political nature, imply dealing with institutions, organizations and people. Nonetheless oral health management in the public scenario has been rarely addressed by recent literature ${ }^{16}$. With the implementation of Unified Health System- UHS-, the Brazilian public policies took responsibility for financing and managing the health services network. Management has been developing a service organization, which seeks to reconcile knowledge about public administration with sanitary effective procedures in order to meet the needs and problems of the population. The Unified Health System- UHS- has been handling participatory management processes and the incentive to social control, involving managers, workers and the civil society. Oral health evaluation: The evaluation of actions can enhance the capacity of the Government, thus contributing to increase the governability of the health system. An important step on this refers to the quality evaluation processes established throughout the country by the Program for Improving Access and Quality of Primary Care (PIAQ PC) and the Dental Specialties Centers (DSC), carried out by the Ministry of Health in partnership with some universities.The wide-ranging evaluation of the Program for Improving Access and Quality - PIAQ has provided an important approach related to the structure, management and working process of the Oral Health Team- OHT- in the primary and specialized areas. The PIAQ has pursued the precise situation of services through the perception of managers, professionals and users' satisfaction with access and use $\mathrm{e}^{17}$. This study was approved by the Research Ethics Committee of the Federal University of Minas Gerais, under the number CAAE number 55925216.5.0000.5149 and was approved by the Regional Health Management (RHM), of State Secretariat of Health-Minas Gerais.

\section{RESULTS AND DISCUSSION}

The planning categories, the work process and social control emerged from the analysis of the material collected.

\section{Planning}

Preceded by UHS, National Oral Health Policy, (NOHP) the National Primary Care Policy (NPCP), and, the National Health Promotion Policy (NHPP) PNAB, the planning actions seem to be a not very effective practice 
in the municipalities studied. According to the oral health coordinator of the Regional Health Management (RHM), a general orientation is carried out for the planning of actions in all municipalities. In this way, when it happens, planning takes place in a standardized way. Although support is provided by the Regional Health Management (RHM) and the Municipal Health Secretariats for planning actions, their accomplishment has been impaired.

"What is advised [...] is that demand and need are provided. risk assessment, risk classification [...] social risk and risk of caries. Then plan. But, each municipality does this according to their understanding, [...] there is no such sequence, you know? "(" $(\mathrm{IA}))$

"Each team decides their actions, the way they will work and everything. The only thing we ask for is the home visit ... prevention ... brushing, epidemiological survey, which is every two years "(IB)

When actions do not take place in a planned way, they can result in a dismantled service, based on unplanned routine and improvisation and without the participation of all the social actors involved. These situations generate "meet urgent demand" actions, and other situations, in disorganized work processes where each one acts in the way that suits him, sometimes seeking focused help, not always clear about the objectives and goals to be achieved.The results showed that epidemiological surveys are little used as resources to guide the work process of the OHT. At most, studies are conducted to get to know the DMFT in schoolchildren of public primary education, or find out about the dental treatment needs of the population's groups. This situation violates the guidelines of the National Oral Health Policy,(NOHP), which advocates the use of epidemiology and information on the territory to support planning, emphasizing the need for a prior diagnosis of the health-disease conditions of the populations, through the family approach and the relationships that are established where the practice of health is developed ${ }^{14}$.

In the planning process municipal coordination very often analyzes and agrees on the indicators to be used and then informs them to the OHT.

"... all the programs come like this, the goals agreed ... if you have an indicator ... of brushing ... we make an agreement with the Regional Health Management (RHM), and then ... they are told that they have to meet the target $X$ ". (ID)

... no, we don't do it together ... I made a sketch and had a meeting with them .. ah! what do you think? ... is it okay? ... Shall we change anything ?. But, it was not built together, not [...] it needs to be more ... participative. " (IH)

This municipal coordination practice reproduces the rigidity observed in the relationship between regional agencies and the municipal structure. In this case, the regional ones act as an orientation pathway from the central level to the municipal ${ }^{18}$. The subjects reported having only partial access to the indicators that could be used in the planning processes.

"We do this monitoring every quarter, when the regional representatives present the indicators" (IE)

"I would like to have access to E-UHS [...] we seek, try, the computer technician does not give us this answer [...] regional people, they do not know either. I wanted to draw them back to interpret "(IE)

According to the Ministry of Health, indicators and parameters can support the analysis of results and the programming of actions of the health services, with the aim of guiding the UH S managers and workers from the Federal, State and Municipal Government of Minas Gerais. They are, therefore, fundamental to the planning, programming, monitoring, evaluation, control and regulation of health actions and services, aiming at integrality and acess equity. It is recommended that they are adequate to the States, Municipalities and Regions of Health, according to the socio-epidemiological and demographic realities, as well as the resources available ${ }^{19}$. Most stated that the institutional support of the Regions of health or the municipal management to the OHT is not present.

"... people at the beginning of the year, meet with the coordinator of oral health and we outline some goals $[. .$.$] the indicators that ... have$ to meet, and ... review this for the team, [..] .] But, I think that's still missing, Dentistry ... I think it's a 
little bit apart ... "(IF)

"And we do not participate in the part of making the agreement, they only inform us, it was agreed, that, ... a difficulty that we face ... we do not have, for example this data. .. " (IF4)

Institutional support, as a management assignment, aims to strengthen individual and collective subjects in the production of institutional democracy. It is a process that reinforces responsibilities and brings, for individuals and teams, the vital technical limits to the work planning and organization. Institutional support can facilitate dialogues, mediate conflicts, stimulate thinking and introduce new possibilities for the work process.. It also strengthens individuals or groups of people towards autonomy and protagonism and also avoids supporter's dependency ${ }^{20}$. The lack of institutional support in the management of health work can jeopardize the development of the subjects' guiding capacity and governance when intervention is necessary. This support aims to increase the capacity of subjects' empowerment and establish relationships at work based on knowledge and affection20. For the interviewees, especially for dentists, the Program for Improving Access and QualityPIAQ- through the Self-Assessment for the Improvement of Access and Quality (SAIAQ), constituted the real possibility of evaluating what is done, how it is done and the perception of what is needed while using intervention matrices.

"And one thing that has helped us a lot is organizing the PIAQ, because it has the SAIAQ), right? And the SAIAQ made us see a lot of things that, sometimes, stuck there at work, ... could not look, really see, then ... we do our SAIAQ [...] ,... there draws the matrices of intervention" ... (FG3)

Another frequent question concerns the attention model centered on the organization of spontaneous demand, which still seems to be hegemonic and reveals a real difficulty for the accomplishment of the planning as advocated by public policies. This situation seems to be reinforced when the planning process has as a goal the reduction of the spontaneous demand for access to oral health services. In these cases, management support should try to adapt the model to the principles and guidelines of UHS.
"... we can't to program much, because we get too caught up in the demand of the city, especially in spontaneous demand. (FG3) "

\section{Work process}

According to the subjects' report, the organization of the OHT work has been in charge of the professionals of each team, despite the Regional Health Management (RHM), guidelines and the Municipal Health Secretariats,. According to dental surgeons, most often, the organization of access is based on the nature of the demand in each health unit.Thus, in general the agenda of these professionals is organized weekly, some of which are the responsibility of $\mathrm{OHT}$, and others of the unit reception desk. Its organization follows the spontaneous demand model, with emphasis on the scheduled patients and emergencies.

"... we schedule ... every Friday [...] only schedules during the week and we leave room for emergencies ... I attend these emergencies throughout the day, [...] and have the patients that I control, as I finish the treatment, new vacancies will appear ... (FG3)

They say ... that the agenda would have to stay at the reception desk and I ... mine ... stays with me or with my oral hygiene technician, ... I do not agree very much, because we are the ones who have [ ...] to know which patient was scheduled, if he missed, [...] so as not to hold on to someone who really wants. " (FG4)

There are situations where agendas are prepared in a more integrated way with other professionals.

"... I provided ... according to the demand ... that day, ... with a nurse and a doctor, $[. .$.$] for us$ to schedule on the same day, ... an elderly, diabetic and hypertensive patient goes there in the unit to follow up. "(FG4)

In some scheduling situations, actions defined are included after the PIAQ: preventive actions, epidemiological surveys and home visits for bedridden. However, the agenda could not always be observed due to the emergencies fulfilled (spontaneous demand model).

Every time I booked a visit, I arrived at the 
Family Health Program, I had 3, 4 emergencies to attend, I attended 3, 4 emergencies, I had the bureaucratic service to do, I said, I'm not going to do the visit. " (FG4)

"I do not have access to the agenda, it's all at the reception [...] the first appointment, the return, the demand is very great too [...] at the beginning I did a lot of prevention, lecture and action in schools, Due to the demand, I'm getting more in the office "

Often there is no access to epidemiological information to evaluate the actions undertaken, and to plan the next ones.

"... because of PIAQ- [...] we made that agenda more times ... did many things that did not have, [...] but we did not have that access, the epidemiological survey in schools, which is what can we see how it is ... "(FG4)

The Ministry of Health through PIAQ and PIAQ -PC proposed the organization of an agenda that would guarantee access not only to appointments, but to group assistance, home visits and other health promotion actions $^{18,21}$. This agenda promotes approaching with the users, aiming to ensure fair and integral assistance. The agenda preparation must take into account a precise diagnosis of the social and epidemiological reality, as well as an analysis of the popolation'srisks and vulnerabilities in order to identify the main problems This diagnosis should base the planning and development of health actions capable of promoting effective access as well as overcome accessibility problems in each region ${ }^{22}$. The UHS still presents standard and centralizing practices ${ }^{23-24}$, in which, the effective participation of professionals in the management process is not always present.

Regarding to the main objective of improving the health of the population the excess of standards, in the presence of authoritarian management, can create a network of unmotivated and uncommitted professionals, resulting in an inefficient system ${ }^{25}$, which in turn can promote mechanic health acts, without real emotional bonds, as if they were serial productions of a professional organization. Often, the goals are not planned by the teams.

"They want numbers, numbers and more numbers (...)" (FG4)

Labor issues, especially wages, were identified as causes which impair the organization of PC as predicted in the National Oral Health Policy- NOHP, which interferes negatively in the increase of access and the resolubility ${ }^{26}$. According to the subjects' reports, none of the municipalities surveyed presented a career plan.

"This is why we had this difficulty ... to set up the oral health team, because the oral health team is eight hours a day, you know? And they, alone, their contract is four, and they all have private practice, where they do not want to, they just want to work the four hours ... " (IC)

Permanent education is a proposal of the UHS and the NOHP ${ }^{14}$. It is an important tool for institutional support and a basis for management qualification, as it brings concepts, in its methodology, that take into consideration the professionals' routine and places managers, health professionals and users as the main actors in the learning process, motivating them to take a proactive role. The need for technical updating, training of the professionals of the $\mathrm{OHT}$ was reported by the interviewees. The professionals reported having very few opportunites for a course, workshop or seminar.

"... we did not have this training, we had the material ... they gave it to us, to read, [...] but we have difficulty with this support because there are things which until now we have a little difficulty to standardize the services. " (FG6)

This situation contrasts with the National Policy on Permanent Education in Health (NPPEH), which is a teaching / learning practice proposal, a health education policy that aims to build and consolidate health work ${ }^{27}$. These are courses, trainings, Internship programs, seminars, workshops and similar events, which can be presential and / or at a distance, offered by the government or educational institutions. They seek to meet the objectives of the services or institutions, and may be proposed by managers and professionals. If, on the one hand, their actions can induce thinking, stimulate participation and protagonism of the subjects, on the other hand they may constitute standardization work impairing the development of skills and competencies of 
professionals to participate in the planning and decisionmaking processes. Considering the negative aspects pointed out as a distortion in the application of National Policy on Permanent Education in Health (NPPEH), there is a risk of discouraging and alienating professionals from work ${ }^{28-29}$. The prevention and control of oral cancer is included in the OHNP as a PC health. Mouth cancer requires specialized and complex treatments that also ask for hospital and recovery interventions. Regarding this issue, the interviewees showed that there is no monitoring process which proposes permanent actions of diagnosis, reference and counter- reference, monitoring and registration.

"Everything works out of friendship, to meet people in Ituiutaba, ... in Uberlândia, who are our guardian angels, who are sensitive to our concern, our lack of service and help us. But legally, formally, the criteria of referral, for this I have not found these doors open until today "(EE).

This is a worrying and undesirable situation, restricted to specific actions, procedures are carried out only when there is disease suspicion or it is confirmed, without the establishment of a formal reference and counter-reference system. This is in contrast to the recommendations of the OHNP, which proposes the control of Mouth Cancer control with the routine implementation of preventive examinations and to ensure treatment continuity of care, at all levels of complexity, through negotiation and agreements with representatives of the three government institutions ${ }^{14}$.

\section{Social control}

Social control is a constitutional guarantee of population participation in the processes of formulating, implementing and evaluating health policies and controlling in all government institutions. According to the reports, social control is perceived a user-only participation. For the subjects of the research, users do not seem to perceive health as a right; therefore health does not play a leading role in the relationships they establish with health services. Participation is restricted to the users' demands for access and information about the operation of the services.

"... I think sometimes there is a lack of clarification for the population ... this is a problem ... very serious, it is the lack of information, they don't give the deserved importance ..." (FG1)

"... because there is no participation here, nor the Municipal Health Council ... has formal meetings to call the people" (II)

The ombudsman's office is the most important mechanism for the user's participation to ask questions, make complaints and suggestions.

"No. He does not participate. Only in this matter of the ombudsman. So we take into consideration what they complain about. (IF)

In smaller cities, participation also takes place when it is possible to share common physical spaces with the professionals.

"... there is that person who ... is not an emergency, a restoration that has fallen, for example, or a nuisance, a sensitivity, which is not necessarily a pain, but we schedule "

Most people are unaware of the participation possibilities, probably due to the misinformation about the existing participation bodies. According to Toro ${ }^{30}$ being a member of a health council or conference is a choice, which must be freely performed by each person. In addition to awareness, it is necessary to know and understand the UHS, its principles and guidelines, and voluntarily decide with responsibility and willingness to participate. Other participation forms may include the official institutions such as the Public Ministry, political parties, the media, participatory budgeting, representative democracy, social networks, associations and professional bodies.

\section{CONCLUSION}

This study revealed the existence of a centralized and poorly participatory planning practice. As for the work process, it is determined by the demand for urgencies and treatment in oral health. No significant forms of user participation and social control were identified. The results point to the need for an effort to reorganize oral health actions in primary care. Health promotion should be ensured through the substitution of the model centered on spontaneous demand for another one referenced in health promotion, which would reflect and respect UHS 
principles. It is of utmost importance that managers and oral health teams work together as to promote a shared management process, with effective workers' and users' participation. Therefore, it is fundamental that we seek to approach social movements and strengthen social control. Planning actions should start from the reality itself, answers and possible advances to be encountered with the resources that are available in each place, for an OHNP development facing problems and demands. In this context, it is of crucial importance that the work process should be strengthened through the organization of team actions. Health promotion strategies should consider social determinants in the planning, implementation and

\section{REFERENCES}

1. Aquilante AG, Aciole GG. O cuidado em saúde bucal após a Política Nacional de Saúde Bucal - "Brasil Sorridente": um estudo de caso. Ciênc Saúde Colet. 2015;20(1):239-48. doi: 10.1590/1413-81232014201.21192013

2. Matos GCMEA. A inclusão da equipe de saúde bucal na Estratégia de Saúde da Família: entraves, avanços e desafios. Ciênc Saúde Colet. 2014;19(2):373-82. doi: 10.1590/141381232014192.21652012

3. Pucca Junior GA. Política nacional de saúde bucal do Brasil, integralidade e acesso: o caso Brasil Sorridente [tese]. Brasília: Universidade de Brasília; 2013.

4. Silveira Filho AD. Avaliação da efetividade das ações de promoção de Saúde Bucal na Atenção Primária à Saúde no SUS: Brasil 2013 [tese].Curitiba: Pontifícia Universidade Católica do Paraná; 2015.

5. Scherer $\mathrm{Cl}$, Scherer MDA. Adavances and challenges in oral health after a decade of the "Smiling Brazil" Program. Rev Saúde Pública. 2015;49(1):1-13. doi: 10.1590/S00348910.2015049005961

6. Yin R. Estudo de caso: planejamento e método. $2^{a}$ ed. Porto Alegre: Bookman; 2001.

7. Yin RK. Estudo de caso: planejamento e método. $3^{\mathrm{a}}$ ed. Porto Alegra: Bookman; 2005.

8. Minas Gerais. Secretaria de estado de saúde. Adscrição e população dos municípios por macrorregião e microrregião de saúde [citado 2016 Dez 20]. Disponível em: <http://www.saude. mg.gov.br/images/documentos/Adscricao \% 20municipiosmicros \%20e\%20macrorregioes \%20pop \%20tcu\%202011. pdf $>$.

9. Instituto Brasileiro de Geografia e Estatística. Cidades [citado 2017 Jan 11]. Disponível em: <http://cidades.ibge.gov.br>

10. Nascimento PAG, Melo NA. Reflexões sobre sua atuação na rede urbana regional a partir dos serviços de saúde e educação. Geo UERJ. 2011;22(2):395-421

11. Datasus. Ministério da Saúde [citado 2017 Jan 11]. Disponível evaluation of their actions. Work based on the territory awareness should seek, through intersectoral actions, the construction of integrality and access to health services.

\section{Collaborators}

SHC ANDRAUS was responsible for the conception, collection, analysis and interpretation of the data, writing the article and final approval of the manuscript. RC FERREIRA, JHL AMARAL, and MAF WERNECK were responsible for the conception, analysis and interpretation of the data, critical review relevant to the intellectual content and final approval of the manuscript.

em: <http://tabnet.datasus.gov.br/cgi/tabcgi.exe?pacto/2015/ cnv/coapcirmg.def>.

12. Bardin L. Análise de conteúdo. Lisboa: Edições 70; 2009

13. Martins GA. Estudo de caso: uma estratégia de pesquisa. $2^{a}$ ed São Paulo: Atlas; 2008

14. Brasil. Ministério da Saúde. Diretrizes para Política Nacional de Saúde Bucal [citado 2016 Dez 20]. Disponível em: <http://189.28.128.100/dab/docs/publicacoes/geral/diretrizes da_politica_nacional_de_saude_bucal.pdf > .

15. Teixeira CFT, Vilabôas ALQ. Modelos de atenção à saúde no SUS: transformação, mudança ou conservação? In: Paim JS, Almeida Filho N. Saúde coletiva: teoria e prática. Rio de Janeiro: Medbook; 2014. p. 121-137.

16. Campos GWS, Campos RTO. Fiocruz. ESPJV [citado 2017 Jan 17]. Disponível em: <www.sites.epsjv.fiocruz.br/dicionario/ verbetes/gessau.html>.

17. Brasil. Ministério da Saúde. Programa Nacional de melhoria do Acesso e da Qualidade da Atenção Básica (PMAQ). Manual instrutivo. Brasília: Secretaria de Atenção à Saúde. Departamento de Atenção Básica; 2012 [citado 2017 Jan 17]. Disponível em: $<$ http://189.28.128.100/dab/docs/publicacoes/geral/manual_ instrutivo_pmaq_site.pdf>

18. Silva EC, Gomes MHA. Impasses no processo de regionalização do SUS: tramas locais. Saúde Soc. 2013:22(4):1106-16.

19. Brasil. Ministério da Saúde. Critérios e parâmetros para o planejamento e programações de ações e serviços da saúde no âmbito do Sistema Único de Saúde. Brasília: Secretaria de Atenção à Saúde, Departamento de Regulação, Avaliação e Controle dos Sistemas; 2015 [citado 2017 Jan 17]. Disponível em: <http://portalsaude.saude.gov.br/index.php/o-ministerio/ principal/secretarias/1123-sas-raiz/drac-raiz/cgpas/16528parametros-cgpas>

20. Pereira Junior N, Campos GWS. O apoio institucional no Sistema Único de Saúde (SUS): os dilemas da integração interfederativa da gestão. Interface. 2014;18(suppl.1):895-908.

21. Brasil. Ministério da Saúde. Política Nacional de Atenção Básica. Brasília: Ministério da Saúde; 2012 [citado 2017 Jan 17]. 
Disponível em: < http://189.28.128.100/dab/docs/publicacoes/ geral/pnab.pdf>

22. Costa AC, Bucky DAC, Monteiro MS, Figueira SMA. Agenda: um desafio para organização do serviço de saúde. São Paulo: Associação Paulista para o Desenvolvimento da Medicina; 2013.

23. Falleiro LDMEA. Considerações preliminares sobre apoio institucional e educação permanente. In: Falleiro LDM. Experiências de apoio institucional no SUS: da teoria a prática. Porto Alegre: Rede Unida; 2014. p. 18-25.

24. Guizard Fl, Cavalcanti FO. A gestão em saúde: nexos entre o cotidiano institucional e a participação política no SUS. Interface. 2010;14(34):633-45.

25. Dussault G. A gestão dos serviços públicos de saúde: características e exigências. Rev Adm Pub. 1992;12(2):8-19.

26. Souza GCDA, Costa IDCC. O SUS nos seus vinte anos: reflexões num contexto de mudanças. Saúde Soc. 19(3):509-17.

27. Cecim RB, Ferla AA. Dicionário da educação permanente em saúde [online] [citado 2016 Out 23]. Disponível em: <http:// www.sites.epsjv.fiocruz.br/dicionario/verbetes/edupersau. html>.
28. Pezzato LM, L'abbate S, Bottazzo C. Produção de micropolíticas no proceso de trabalho em saúde bucal: uma abordagem socioanalítica. Ciênc Saúde Coletiva. 2013:18(7):2095-104.

29. Davini MC. Enfoques, problemas e perspectivas na educação permanente dos recursos humanos de saúde. In: Brasil. Ministério da Saúde. Secretaria de Gestão do Trabalho e da Educação na Saúde. Departamento de Gestão da Educação em Saúde. Política Nacional de Educação Permanente em Saúde [Internet]. Brasília; 2009 [citado 2016 Out 15]. Disponível em: $<$ http://bvsms.saude.gov.br/bvs/publicacoes/politica_nacional_ educacao_permanente_saude.pdf>

30. Toro JB, Werneck NMD. Mobilização Social: um modo de construir a democracia e a participação. Belo Horizonte: Comunicação e Mobilização Social 2; 2004.

Received on: 31/1/2017

Final version resubmitted on: 5/5/2017

Approved on: 29/6/2017 